\title{
RESPIRATORY DISEASES OF CHILDREN LIVING NEAR A DUMPSITE
}

\section{DOENÇAS RESPIRATÓRIAS DE POPULAÇÃO INFANTIL RESIDENTE PRÓXIMA A UM LIXÃO}

\author{
Claudio Fernando MAHLER ${ }^{1}$; Saulo Barbará de OLIVEIRA ${ }^{2}$; Stella Regina TAQUETTE \\ 1. Programa de Pós-Graduação em Engenharia Civil, Grupo de Estudos em Tratamento de Resíduos Sólidos, Universidade Federal do \\ Rio de Janeiro - UFRJ - COPPE, Rio de Janeiro, RJ, Brasil; 2. Programa de Pós-Graduação em Gestão e Estratégia, Universidade \\ Federal Rural do Rio de Janeiro - UFRRJ, Seropédica, RJ, Brasil. saulobarbara@ gmail.com; 3. Departamento de Pediatria, Universidade \\ do Estado do Rio de Janeiro, Rio de Janeiro, RJ, Brasil.
}

\begin{abstract}
Despite recognition of the socioenvironmental impacts of improper manangement and disposal of municipal solid waste (MSW), often involiving diseases, few studies have been carried out to investigate the association between this waste management and health. It is important to know the health status of people living near landfills and dumps, to make those responsible for managment aware of the need to establish more effective sanitation policies. For this purpose, we conducted a descriptive case study with primary data on repiratory diseases of children living near a trash dump. The field work was performed in two periods in 2005 and 2016. In the first, the dump was in operation, while in the second it had been shut down for about five years. The study was conducted in a city in the state of Rio de Janeiro with a population of about 47,000 people in 2006. The results indicate that the rates of respiratory diseases among children living in the area surrounding the dump were higher in 2005 than in 2016, a finding that might be related to the dump's closure. In ten cases the decline in the ailments reported by the respondents was significant, led by wheezing attacks after exercise (26.4 percengage points lower) and pneumonia (16 p.p.lower). In six cases, the rates were slightly higher, suggesting the need for a more thorough study to investigate this increase. The results are not definitive, but indicate the importance of the considering the negative health effects of trash dumps and the need to close them or improve the treatment and disposal of municipal solid waste.
\end{abstract}

KEYWORDS: Solid Waste Landfill. Trash Dump. Public Health. Respiratory Ailments. Child Health. Environmental Pollution.

\section{INTRODUCTION}

Contamination of the soil and groundwater has been a growing global worry in recent decades, and is known to be a serious problem that particularly afflicts large urban and industrial centers. Currently, a large portion of the Brazilian population is exposed to various types of risks, resulting in high vulnerability, both in urban and rural areas. Factors related to topography, rainfall regime, soil sealing in urban areas, insufficient collection and inadequate disposal of municipal solid waste (MSW) and hazardous substances can aggravate these risks. Because of these factors, the problems caused by contaminated and degraded areas are increasing, although there is insufficient knowledge to identify the geographical variation of these effects and prescribe mitigating measures. The resulting health problems particularly afflict people of lower economic classes. More effective integrated collection and treatment of MSW are essential for the sustainable development of urban centers (USÓN et al., 2013). Brazil as a whole suffers from lack of care by public authorities and the people who live near water bodies, causing alarming levels of contamination in many points due to discharge of raw sewage and dumping of untreated MSW.

In Brazil in particular, the solution to the problems of air and water pollution depends on the action of environmental agencies to establish a set of measures to discover the characteristics and impacts caused, so the information obtained can support rigorous actions to deter violation of rules, change attitudes and remove or mitigate the sources of environmental damages. In other words, it is necessary to establish a clear approach regarding the most suitable forms and levels of intervention, to reduce the health risks and improve the safety of the population. Unfortunately, the population and public authorities often do not act responsibly with respect to pollution control, to the detriment of society as a whole.

With respect to solid waste landfill facilities, which can be classified as adequate or inadequate according to the new definition of the São Paulo State Environmental Company (CETESB, 2013), several studies have indicated their negative effects on the health of the surrounding population, especially of children and elderly people. Inadequate disposal sites, either uncontrolled trash dumps or controlled landfills, obviously have a greater chance to contaminate the 
soil, water and air, with worse effects on the health of nearby residents, than those caused by properly managed sanitary landfills.

The problem of inadequate final disposal of MSW in Brazil is directly related to public mismanagement and the hidden interests of municipal government officials and private contractors (e.g., possible kickbacks for trash collection and disposal contracts). In more developed countries such as in the European Community, which have already learned to take maximum advantage of trash through recycling, energy generation and other technologies, the disposal of MSW in landfills has been drastically reduced (DOMINGO et al., 2015).

However, despite the significant benefits of these environmentally sound waste management practices, most MSW in Brazil is still simply sent to dumps or landfills. Consequently, the participation of MSW in energy generation in Brazil is tiny (MAIER; OLIVEIRA, 2014).

Brazil also suffers from a lack of studies of the health risks posed by trash disposal sites. Furthermore, there is a dearth of technical criteria to assess the post-closure environmental risks, as well as of suitable strategies for protection of the environment and human health. (SCHUELER; MAHLER, 2011)

In developing countries, about a third of the population lives in cities with environmental conditions conducive to the spread of parasitic infections, reaching levels of $90 \%$, with a significant increase with decreasing socioeconomic level (VIEIRA; BENETTO, 2013, p.487).

In industrialized countries, the search for methods to assess the risks to human health and the environment has been gaining importance as sanitary authorities and environmentalists become more aware of the pollution potential of the large volume of trash generated daily (DOLK et al., 1998; PORFIRIO et al., 2014).

The effort to formulate concepts to identify and locate areas that pose risks to human and environmental health is crucial, because the longterm practical effects on humans, animals and plants are potentially severe, far outweighing the costs of mitigation measures (GOLDENBER, 2000).

For some authors, such as Mattiello et al. (2013), no doubt exists of the risks posed by trash disposal sites to the environment and the health of the people living nearby, due to the emissions of harmful substances, even in very small quantities, a position only partially corroborated by Dolk et al. (1998) and Vrijheid (2000), among other surveyers.
The study by Vrijheid (2000) indicated problems for people living near solid waste landfills in Europe, such as lower birth weight and higher rates of congenital defects, some types of cancer, allergies, asthma and other respiratory ailments. Dolk et al. (1998) described a 33\% increase in combined birth defects among people living less than $3 \mathrm{Km}$ from waste disposal sites in 10 European regions. They also found significantly higher incidences of central nervous system deficiencies and cardiac problems.

Guida et al. (2010) investigated the genotoxic effects of environmental chemicals on women living near sanitary landfills in Italy by analyzing samples of amniotic fluid and detected DNA damage through changes in randomly amplified polymorphism DNA profiles.

The question of the possible health risks is subject to controversy, and can be explained by the huge range of variables that can affect outcomes, themselves subject to nuanced interpretations. Therefore, there is a great need for further survey, particularly in Brazil, where the problems from mismanagement of MSW are more severe and widespread than in developed countries.

Unfortunately, of the more than 5,570 Brazilian municipalities ${ }^{1}$, more than 2,500 dispose of their solid wastes in open dumps. The target set by the National Solid Waste Management Policy (PNRS, 2010), of ending use of uncontrolled dumps by 2014, has not been met and the effects of these inadequate facilities on the environment and nearby people still represent a serious problem.

According to data from the most recent National Sanitation Survey conducted by the Brazilian Institute of Geography and Statistics (IBGE), daily generation of MSW in the country amounts to 259,547 metric tons, of which 86,451 tons/day (35.39\%) does not have proper disposal, being sent to dumps, marshy/flooded areas or controlled landfills. In other words, of the total mass collected daily, only $64.61 \%$ (167,636 tons) goes to sanitary landfills. Table 1 shows more details (IBGE, 2008).

\footnotetext{
1 The municipality is the local administrative unit in Brazil. It is akin to a county, except with a single mayor and municipal council. Municipalities range from lightly populated rural ones with one or two small towns to heavily populated urban ones that are part of greater metropolitan regions. There are no unincorporated areas in Brazil.
} 
Table 1. Destination of solid wastes in Brazil

\begin{tabular}{ccccccccc}
\hline \multicolumn{7}{c}{ Quantity of solid wastes (household and public) collected or received (t/day) } \\
\hline Total & \multicolumn{7}{c}{ Final disposal site of solid wastes collected or received } \\
& Dump & $\begin{array}{c}\text { Marshy/ } \\
\text { flooded } \\
\text { areas }\end{array}$ & $\begin{array}{c}\text { Controlled } \\
\text { landfill }\end{array}$ & $\begin{array}{c}\text { Sanitary } \\
\text { landfill }\end{array}$ & $\begin{array}{c}\text { Composting } \\
\text { Unit }\end{array}$ & $\begin{array}{c}\text { Sorting/recycling } \\
\text { unit }\end{array}$ & $\begin{array}{c}\text { Treatment } \\
\text { and } \\
\text { incineration } \\
\text { unit }\end{array}$ & Other \\
259,547 & 45,710 & 46 & 40,695 & 167,636 & 1,635 & 3,122 & 67 & 636 \\
\hline Source: IBGE (2008) & & & & & & & & \\
\end{tabular}

Therefore, 86,451 tons/day does not have proper disposal, and 40,695 tons/day goes to controlled landfills, where the only type of treatment is generally daily coverage of the waste with inert material, which alone is not sufficient to protect the environment. Worse, the remainder is thrown away, mainly by low-income people (due to lack of collection by public authorities), on hillsides, in water courses, vacant lots, etc. The resulting dumps lack any measures to protect the environment or public health.

Although in recent years the disposal of trash in Brazil has improved greatly, much improvement is still needed, since according to the most recent statistics available, $35.38 \%$ of the solid waste generated daily still is not handled properly. Hence, there is a need to increase the volume receiving some type of treatment (recycling, composting or incineration after removal of toxic material), which only amounts to 4,824 tons/day. Furthermore, unfortunately not all the landfills classified as sanitary have adequate monitoring systems that can assure prompt efforts to control possible gas emissions, formation of underground contamination plumes, dangerous movements of the waste mass or formation of leachate pools, as well as accumulation of gases within the mass (MAHLER et al., 2002).

As seen, according to various authors the proximity of residential areas to solid waste disposal sites can affect the severity of the health impacts on the local population. This fact was the main element motivating the present study.

In another study of the effects of gas emissions on children living around the same dump site, carried out in the same year, Real (2005) called attention to the "index of deaths due to diseases of the respiratory tract" noted in a study by the IBGE in 2003. More specifically, he stated that "the index in the municipality investigated was more than triple the average found in neighboring municipalities and others considered as having the same size in the state of Rio de Janeiro" and that "considering the scope and representation of the surveys of the
IBGE, this is a finding that should be considered in future studies of the municipality" (REAL, 2005, p. 163).

We investigated the children living in the vicinity of a waste dump located in a municipality in Rio de Janeiro state, to evaluate the respiratory health of this population, in two periods, one when it was in full operation and the other five years after its closure, in 2005 and 2016 respectively.

\section{MATERIAL AND METHODS}

Location and characteristic of the surveyed areas

The municipality studied has an area of $179,680 \mathrm{Km}^{2}$. In 2008, its estimated population was 47,124 people, with demographic density of 260 inhabitants $/ \mathrm{Km}^{2}$ (IBGE, 2010).

Among the municipalities in the state of Rio de Janeiro, at that time it had the worst respiratory health indices (IBGE, 2012). For many years, its trash dump was one of the main environmental problems of the municipality. The location of this facility was a particular problem, because the central part of the town was constantly affected by the odors. The dump caused contamination to the soil, water and air.

Between 1975 and 2005, all the MSW generated in city studied was taken to this inadequate dump site, located about 20 meters from the Macacos River. This river traverses the municipality and is an affluent of the Lajes River, one of the main water courses in the Guandu River Basin, responsible for water supply to the city of Rio de Janeiro and several outlying municipalities (MUSQUIM; OLIVEIRA, 2002).

The establishment of this dump created a barrier between the two districts forming the municipality. Therefore, the presence of the dump posed an obstacle to the natural expansion of the urban area.

The dump was deactivated in 2011 and replaced by a sanitary landfill, located along state highway RJ 093, in the direction of the adjacent municipality of Japeri, only a few kilometers from 
the old site. This contributed to an increase in the population residing in the area around the old dump. Currently about 100 families live in this area, while in 2005 there were about 50 families, from which health data on 80 children were collected, in the first survey, and 22 children in the second survey.

Much of the area of the municipality studied is used for farming and stock breeding. The climate is hot tropical (average temperature above $18{ }^{\circ} \mathrm{C}$ ) or moderate (between $18^{\circ} \mathrm{C}$ and $15^{\circ} \mathrm{C}$ ) and moist (only one two three dry months). The air temperature varies from $18{ }^{\circ} \mathrm{C}$ to $30{ }^{\circ} \mathrm{C}$, and average yearly rainfall is $1,224.9 \mathrm{~mm}$, with most occurring between November and April (the hottest months) and monthly averages ranging from 109.2 $\mathrm{mm}$ (April) to $196.1 \mathrm{~mm}$ (January). The trash dump site is located in an area with gentle inclination at the foot of a slope rising from the Macacos River. This topography facilitates the flow of part of the water and sediments from the hillside to the river, passing through the dump site and the surrounding houses. Because of their location in a valley at the foot of a hillside, the homes are subject to strong winds, carrying particulate matter from the dump (SCHUELER, 2005; SCHUELER; MAHLER, 2011)

\section{Epidemiological aspects}

This is a non-randomized study, which took into account the criteria of convenience and accessibility for site selection and survey subjects. The study is descriptive, qualitative and quantitative, but here we only present the results of the quantitative investigation, as mentioned before. The field survey was a case study, in which we evaluated the respiratory health conditions of the target population.

As stated, we conducted two field surveys, the first in March-April 2005 and the second in August 2016. In both, primary data were collected by a translated version of a questionnaire developed by the Division of Lung Diseases of the National Heart, Lung and Blood Institute in the United States. This questionnaire is designed to assess the respiratory health of people, and is divided into two parts, the first targeted at adults and the second to children. We used the second part of the questionnaire (NHLBI-US, 1986, pp. 36-47).

Although the questionnaire has 43 questions, in the data treatment we only included the questions where the responses were considered consistent.

In the first survey we applied this questionnaire to children at three primary schools (in Brazil six to twelve years old), two located very near the dump and one located $2 \mathrm{Km}$ away. The questionnaire was handed out to 200 children in the schools and they were asked to take them home and have their parents or guardians respond to the questions on the respiratory health. The questionnaires were collected on two occasions, 15 and 25 days after delivery. About 100 questionnaires were returned, of which 80 were judged suitable for inclusion in the study.

In the second survey, the data were gathered by two researchers, who visited the residences of people living in the area around the dump site. Each interview lasted about 40 minutes. The researchers were accompanied by a member of the community who had agreed to act as a facilitator.

The questionnaire contains 43 questions regarding the following specific health complaints: (a) Coughing; (b) Congestion and/or catarrh; (c) Wheezing, (d) Disease of the thorax; (e) Allergies; and (f) Other diseases.

The data from the surveys were recorded on the questionnaires and then were transferred to a matrix in an Excel spreadsheet, from which we calculated the descriptive statistics by counting the responses tabulated. The percentages of positive responses to the questions in each group out of the total number of people surveyed were calculated by the following formula:

$$
\mathrm{X}=\frac{\mathrm{N} \times 100}{\mathrm{~T}}
$$

Where:

$\mathrm{X}=$ percentage of children;

$\mathrm{N}=$ total positive responses;

$\mathrm{T}=$ total questionnaires completed.

In the first survey, we carried out a pretest of the questionnaire directly with the parents of five children, who answered the questions of the respiratory health of their kids.

Therefore, the study was conducted in three stages: pre-test questionnaire (in the first case); completion of field survey; and tabulation and statistical analysis of the collected data. In addition, as mentioned previously, we also carried out an exploratory and qualitative survey among the families living around the dump site, whose results were reserved for another article.

\section{RESULTS}

The composition of the waste is the most important factor in assessing the potential for generation of biogas from a disposal site. The 
potential maximum volume of biogas depends on the content of the trash, since organic wastes undergoing decomposition are the source of all the biogas produced. The composition of the waste in the dump was mainly organic material (63\%), followed by paper (34\%) and rags, glass and metal (each with 1\%) (URRJ, cited in MUSQUIM and OLIVEIRA, 2002)
Based on this waste composition, it is possible to conclude that the dump generated a large volume of gases at the time of the study. As stated by Porto et al. (2004), the gases generated by waste disposal sites can potentially cause respiratory problems.

Table 2 shows the comparison of the results on the respiratory health of children, found in the first and second surveys.

Table 2. Comparison of health of children living near the dump site (in percentage)

\begin{tabular}{lrrr}
\hline Evidence of diseases of the respiratory tract & $\begin{array}{c}\text { First } \\
\text { survey } \\
(2005)\end{array}$ & $\begin{array}{c}\text { Second } \\
\text { survey } \\
(2016)\end{array}$ & \begin{tabular}{r} 
Difference \\
\cline { 2 - 4 } Children with coughing not caused by colds
\end{tabular} \\
Chest congestion or catarrh not associated with colds & 26.2 & 22.7 & -11.5 \\
Coughing attack, chest congestion or catarn for one or more & 28.7 & 18.1 & -3.5 \\
weeks/year & & & -10.6 \\
Wheezing causing shortage of breath & 28.7 & 22.7 & -6 \\
Had two or more of this episode & 10.0 & 9.0 & -1 \\
Needed some form of treatment & 16.2 & 18.1 & +1.9 \\
Suffers wheezing after engaging in strenuous exercise & 40.0 & 13.6 & -26.4 \\
Had some disease affecting the chest that prevented normal & 11.2 & 13.6 & +2.4 \\
activities for up to three days & & & \\
During these diseases, more phlegm released & 8.7 & 9.0 & +0.3 \\
Has suffered from sinusitis & 3.7 & 9.0 & +5.3 \\
Bronchitis & 22.5 & 13.6 & -8.9 \\
Pneumonia & 25.0 & 9.0 & -14 \\
Has had tubes placed in the ears for drainage & 3.7 & 4.5 & +0.8 \\
Had tonsils and/or adenoids removed & 2.5 & 0.0 & -2.5 \\
A doctor diagnosed asthma & 2.5 & 4.5 & +2 \\
A doctor diagnosed allergy to some food, medicine, dust or pollen & 37.5 & 31.8 & -5.7 \\
\hline
\end{tabular}

- $47.5 \%$ of the respondents were girls and $52.5 \%$ were boys in the first survey, and $45.4 \%$ were girls and $54.5 \%$ were boys in the second survey.

- $78.7 \%$ were in the age range of 10 to 13 years in the first survey and $68.1 \%$ in the second survey.

- $72.5 \%$ were in the 5 th grade in the first survey and $72.7 \%$ in the second survey.

- $88.7 \%$ were white or mixed-race in the first survey and $77.2 \%$ in the second survey.

$-71.2 \%$ had been born in the city studied in the first survey, and $95.4 \%$ in the second survey.

- $61.2 \%$ lived at the same address for more than five years in the first survey, and all of them in the second survey.

\section{About living situation:}

In the first survey the majority of the children $(65 \%)$ slept with at most one other person in the same bedroom, and of these, $80.7 \%$ slept alone on a bed. The figures in the second survey were $22.7 \%$ and 72.7 , respectively.

In the first survey, $75 \%$ did not live with smokers. In the second survey this rate was $97.5 \%$.

In the first survey $56.2 \%$ lived in residences with 3 or 4 rooms. In the second survey this rate was $63.6 \%$.

In the first survey $76.2 \%$ lived in households with 3 to 5 people. In the second survey the figure was $86.3 \%$.

In the first survey $92.5 \%$ of the homes had stoves using compressed gas. In the second survey all of them had this kind of stove. 
In the first survey $38.7 \%$ did not have any animals at home. In the second survey all of them had some kind of animal (dog, cat or bird).

With respect to health (coughing, chest congestion or catarrh, and others):

$-38.7 \%$ stated they had suffered coughing episodes not caused by colds in the first survey, and in the second survey the rate was $27.2 \%$, a decline of more than 10 percentage points.

- $26.2 \%$ reported chest congestion or catarrh not caused by colds in the first survey, and $22.7 \%$ in the second survey, a small decline of 3.5 percentage points.

$28.7 \%$ reported having suffered coughing attacks, chest congestion or catarrh for one week or more/year in the first survey, while in the second survey this was $18.1 \%$, a decline of over 10 percentage points.
- $40 \%$ reported wheezing attacks after exercise in the first survey, while in the second survey this was just $13.6 \%$, a steep drop of 26.4 percentage points.

$-11.2 \%$ had suffered a respiratory illness that prevented normal activities for up to three days in the first survey, while in the second survey this was $4.5 \%$, a slight drop of 6.7 percentage points.

$-8.7 \%$ released more phlegm during these illnesses in the first survey, and in the second survey this was 9\%, a small decline of 2.3 percentage points.

- $37.5 \%$ had been diagnosed as allergic to some food, medicine, dust or pollen in the first survey, while in the second survey this was $31.8 \%, 5.6$ percentage points less.

Table 3 reports some measures of central tendency and dispersion of chest congestion or catarrh.

Table 3. Measures of central tendency and dispersion

\begin{tabular}{|c|c|c|c|}
\hline \multicolumn{4}{|c|}{ First survey } \\
\hline Mean & $\begin{array}{l}\text { Standard } \\
\text { Deviation }\end{array}$ & Maximum & Minimum \\
\hline 27.3 & 12.9 & 40.0 & 8.7 \\
\hline \multicolumn{4}{|c|}{ Second survey } \\
\hline 17.2 & 11.1 & 31.8 & 2.3 \\
\hline
\end{tabular}

\section{Other respiratory ailments}

- $3.7 \%$ reporting having had sinusitis in the first survey and 9.05 in the second survey, an increase of 6.3 percentage points.

- 22.5\% reporting having had bronchitis in the first survey and $13.6 \%$ in the second survey, a decline of 8.9 percentage points.
- $25 \%$ reported having had pneumonia in the first survey and $9.0 \%$ in the second survey, a drop of 16 percentage points.

- $16.2 \%$ reported suffering from asthma in the first survey and $4.5 \%$ in the second, a decline of 11.5 percentage points.

Table 3 shows some measures of central tendency and dispersion of these ailments.

Table 3. Measures of central tendency and dispersion

\begin{tabular}{|c|c|c|c|}
\hline Mean & \multicolumn{3}{|c|}{ First survey } \\
& $\begin{array}{c}\text { Standard } \\
\text { Deviation }\end{array}$ & Maximum & Minimum \\
\hline 16.9 & 9.5 & 25.0 & 3.8 \\
\hline \multicolumn{4}{|c|}{ Second survey } \\
\hline 9.0 & 3.7 & 13.6 & 4.5 \\
\hline
\end{tabular}

\section{DISCUSSION}

This study investigated the prevalence of respiratory diseases among children living near a dumpsite, where the main disease indices declined five years after its closure. The results indicate more directly that the reduction might be associated with the closure of the trash dump. However, other factors also could have contributed: a) improved standard of living of these families; b) reduction in the number of smokers per dwelling; c) disappearance of dwelling using firewood for cooking; and d) reduced presence of particulate matter in the air. 
From the first to the second survey, some of the indices suggest more significant reduction.

The number of children who sleep in a room with at least one other person declined $42.3 \%$, and $8 \%$ for those sleeping in the same bed with one or more other persons. The average number of smokers per residence also declined, by $22.5 \%$ in residences in general, and increased by $10.1 \%$ in residences with 4 or 5 rooms. Finally, in the second survey, no respondents reported cooking with woodstoves.

Regarding the occurrence of coughing, congestion or catarrh, the following indices should be mentioned: decline of $11.5 \%$ in the number of children with coughs not caused by colds, $10.6 \%$ fewer children suffering from coughing attacks, chest congestion or catarrh for a week or more per year, and $26.4 \%$ fewer children with wheezing crises.

With respect to other respiratory problems, the number of cases of children with breathing difficulty after some type of physical exercise declined $6.7 \%$, the number of kids with some type of allergy fell by $5.6 \%$, occurrences of bronchitis declined by $8.9 \%$, pneumonia cases decreased by $16 \%$, and the asthma rate fell by $11.5 \%$.

\section{CONCLUSIONS}

At the time of the first survey, the city studied was among the roughly half of Brazilian municipalities with environmental problems due to mismanagement of MSW. Besides the bad smell, visual ugliness, presence of vultures, rats and mosquitoes, emission of particulate matter, gases and leachate, etc., the dump studied, located close to the city center, caused environmental damage and a range of health maladies for the people living around it.

In contrast, at the time of the second survey, the dump had been closed for some five years and we observed a considerable reduction of these problems, although noting the emission of gases through drain pipes. We also observed the presence of leachate flowing toward the Macacos River, In general, all those interviews reported discomfort because of the foul odor.

In the first survey, we found a higher incidence of respiratory problems among the population investigated in comparison to the second one, with the declines in the indicators of problems in 10 questions, such as a drop of 10 percentage points in problems related to coughing, chest congestion or catarrh. In the case of wheezing attacks after exercise the decline was 26.4 percentage points, for pneumonia 16 percentage points and for asthma 11.5 percentage points.

Of particular interest is the fact, as stated in the introduction, that in 2003 the city studied had a death rate from respiratory problems three times the statewide average.

Therefore, despite the findings of other researchers of non-significant indices of diseases among people living near MSW landfills, especially in developed countries, as reported in the studies described before in this article, the Brazilian case, and that of the state of Rio de Janeiro in particular, stands apart. The high percentage of Brazilian municipalities that still do not have adequate waste treatment is an indication that the problem of negative health impacts caused by living near dump/landfill sites is far from being solved.

Comparison of the results of the first and second surveys indicates that the health problems of the children living near the former trash dump diminished after its closure, in some cases significantly.

Due to the limited samples size and the normal difficulties of measuring questions involving health problems, new studies should be conducted, including in other places with similar conditions.

\section{ACKNOWLEDGEMENTS}

We thank CAPES, CNPq and FAPERJ for funding, the biologist Bruno Iespa, and the technical advisor Mario de Araujo de Almeida Neto for technical assistance.

RESUMO: Apesar de reconhecidos os impactos socioambientais causados pelo manejo e disposição irregulares dos resíduos sólidos urbanos (RSU), muitas vezes relacionados à incidência de doenças, poucos estudos têm sido realizados com o intuito de verificar a associação entre os efeitos do seu gerenciamento inadequado e a saúde. É importante conhecer o estado de saúde da população residente nas proximidades de aterros de RSU visando conscientizar os responsáveis pelo seu gerenciamento sobre a necessidade de estabelecer políticas mais efetivas nos programas de saneamento dos Estados. Para isso, foi feito um estudo de caso descritivo e quantitativo com dados primários sobre doenças respiratórias de crianças residentes no entorno de um lixão. As pesquisas de campo foram feitas em duas épocas distintas: em 2005 e 2016. Na primeira pesquisa o lixão se encontrava em operação, enquanto que na segunda pesquisa, estava desativado há cerca de cinco anos. O estudo foi desenvolvido numa cidade do Estado do Rio de Janeiro com população aproximada de 47.000 habitantes em 2006. Os resultados dão conta de que as doenças do trato respiratório em 
crianças residentes próximas ao aterro estudado apresentam índices mais elavados, na primeira, com declínio, na segunda pesquisa, e que este fato pode estar relacionado com o fechamento do lixão. Em dez casos o declinio das doenças relatadas pelos sujeitos da pesquisa é significativo, como por exemplo, assovio ou chiado no peito (de $26.4 \%$ menor) e pneumonia (16\% menor). Em outros 6 casos os índices são levemente mais elevados, sugerindo a necessida de realização de um estudo mais profundo de modo a investigar este aumento. Os resultados não são definitivos, mas indicam a importância de fechamento dos lixões, seus possíveis efeitos negativos à saúde e melhores tratamentos e disposições de residuos solidos urbanos.

Palavras ChaVe: Aterro de Residuos Sólidos. Depósito de Lixo. Saúde Pública; Trato Respitatório. Poluição Ambiental.

\section{REFERENCES}

CETESB. Inventário Estadual de Resíduos Sólidos Urbanos, 2012 - CETESB. Coordenação Cristiano Kenji Iwai, Maria Heloisa P. Assumpção; redação Maria Heloisa P. Assumpção, Cristiano Kenji Iwai; equipe técnica Maria Heloisa P. Assumpção, et al. São Paulo, 2013.

DOLK, H.; VRIJHEID, M.; ARMSTRONG, B.; ABRAMSKY, L.; BIANCHI, F.; GARNE, E.; NELEN, V.; ROBERT, E.; SCOTT, J. E.; STONE, D. Risk of congenital anomalies near hazardous-waste landfill sites in Europe: the EUROHAZCON study. Lancet., London, v. 352, n. 9126, p. 423-427, aug., 1998.

DOMINGO, J. L.; ROVIRA, H.; NADAL, M.; FIGUERAS, M. J.; SCHUHMACHER, M. Health Risks for the population living in the vicinity of an Integrated Waste Management Facility: Screening environmental pollutants. Science of Total Environment, Amsterdam, v. 518-519, p. 363-370, jun., 2015.

http://dx.doi.org/10.1016/j.scitotenv.2015.03.010

FIELDER, H. M. P.; POON-KING, C. M.; MOSS, N.; COLEMAN, G. Assessment of impact on health of residents living near the Nant-y-Gwyddon landfill use: retrospective analysis. BMJ., London, v. 320 (7226), p. 19-23, jan., 2000. http://dx.doi.org/10.1136/bmj.320.7226.19

FORASTIERE, F.; BADOLONI, C.; DE HOOGH, K.; VON KRAUS, M. K.; MARTUZZI, M.; MITIS, F.; PALKOVICOVA, L.; PORTA, D.; PREISS, P.; RANZI, A.; PERUCCI, C. A.; BRIGGS, D. Health impact assessment of waste management facilities in three European countries. Environmental Health., London, v. 2, p. 10-53, jun., 2011. http://dx.doi.org/10.1186/1476-069X-10-53

GOLDENBER, M. A arte de pesquisar: como fazer pesquisa qualitativa em Ciências Sociais. Rio de Janeiro: Record, 2000, $57 \mathrm{p}$.

GUIDA, M.; GUIDA, M.; DE FELICE, B.; SANTAFEDE, D.; D’ALESSANDRO, F.; SARDO, A.D.S.; SCOGNAMIGLIO, M.; FERRARA, C.; BIFULCO, G.; NAPPI, C. Assessment of DNA Damage by RAPD in Paracentrotus lividus Embryos Exposed to Amniotic Fluid from Residents Living. Journal of Biomedicine and Biotechnology., New York, v. 1, Article ID 251767, 7 pages, jul., 2010.

IBGE. Pesquisa Nacional de Saneamento Básico - 2008. Available at:

$<$ http://www.ibge.gov.br/home/estatistica/populacao/condicaodevida/pnsb2008/>. Consulted on: September 10, 2015.

Censo 2010, Cidades. Available at:

$<$ http://cidades.ibge.gov.br/painel/painel.php?lang=\&codmun=330360>. Consulted on: August 20, 2016.

. Produção de Paracambi: dados de 2012. Available at:

<http://www.cidades.ibge.gov.br/xtras/grafico_cidades.php?lang=\&codmun=330360\&idtema=134\&search=rio -de-janeirolparacambilproduto-interno-bruto-dos-municipios-2012>. Consulted on: August 30, 2015.

MAHLER, C.F.; ARAÚJO, F.; PARANHOS, R. . Poluição: poluição aquática e resíduos sólidos. Rio de Janeiro: Núcleo de Produção Editorial Aquarius/Fundação Bio-Rio, 2002. 132 p. 
MAIER, S.; OLIVEIRA, L. B. Economic feasibility of energy recovery from solid waste in the light of Brazil's waste policy: The case of Rio de Janeiro. Renewable and Sustainable Energy Reviews., Washington DC, n. 35, p. 484-498, may, 2014. http://dx.doi.org/10.1016/j.rser.2014.04.025

MATTIELLO, M.; CHIODINI, P.; BIANCO, E.; FORGIONE, N.; FLAMMIA, I.; GALLO, C.; PIZZUTI, R.; PANICO, S. Health effects associated with the disposal of solid waste in landfills and incinerators in populations living in surrounding areas: a systematic review. Int J Public Health., Bern, n. 58, p. 725-735, jul., 2013. http://dx.doi.org/10.1007/s00038-013-0496-8

MUSQUIM, V. S.; OLIVEIRA, C. L. S. Aspectos da política municipal de resíduos sólidos do município de Paracambi - R.J. Rio de Janeiro, NADC/UFRJ, 2002, 132 p.

NHLBI-US. Recommended Respiratory Disease Questionnaires for Usewith Adults and Children in Epidemiological Research, 1986. Availabe at:

$<$ https://www.thoracic.org/statements/resources/archive/rrdquacer.pdf>; Consulted on: July 22, 2004.

PACHECO, E. B. A. V.; RONCHETI, L. M.; MASANET, E. An Overview of Plastic Recycling in Rio de Janeiro. Resources, Conservantion and Recycling,. Bern, n. 60, p. 140-146, dec., 2012.

http://dx.doi.org/10.1016/j.resconrec.2011.12.010

PNRS. Politica Nacional de Residuos Solidos: Lei no. 12.310, de 2 de agosto de 2010. Available at: <https://www.planalto.gov.br/ccivil_03/_ato2007-2010/2010/lei/112305.htm>. Consulted on: September 11, 2015.

PORFIRIO, B.; GOMES, J.; JANISSEK, P. R. Human health risk assessment of the municipal solid waste landfill at Morretes. Eng Sanit Ambient., Rio de Janeiro, v. 19 n. 4, p. 441-452. oct./dec., 2014. http://dx.doi.org/10.1590/S1413-41522014019000000444

PORTO, M. F. S.; JUNCÁ, D. C. M.; GONÇALVES, R. S.; FILHOTE, M. I. F. Lixo, trabalho e saúde: um estudo de caso com catadores em um aterro metropolitano no Rio de Janeiro, Brasil. Cad. Saúde Pública., Rio de Janeiro, v. 20, n. 6, p. 1503-1514, nov./dec., 2004.

REAL, J. L. G. Riscos Ambientais em Aterros de Resíduos Sólidos com Ênfase na Emissão de Gases. 2005. 173 f. Dissertação (Mestrado em Engenharia Civil) - Curso de Pós-Graduação em Engenharia Civil. Universidade Federal do Rio de Janeiro, Rio de Janeiro, 2005.

SCHUELER, A. S. Estudo de caso e proposta para classificação de áreas degradadas por disposição de resíduos sólidos urbanos. 2005. 278 f. Tese (Doutorado em Engenharia Civil) - Curso de Pós-Graduação em Engenharia Civil, Universidade Federal do Rio de Janeiro, Rio de Janeiro, 2005.

SCHUELER, A. S.; MAHLER, C. F. Classification Method for Urban Solid Waste Disposal Sites. Journal of Environmental Protection., Delaware, v. 2, p. 473-481, jun., 2011. http://dx.doi.org/10.4236/jep.2011.24055.

USÓN, A. A.; FERREIRA, G.; VÁSQUEZ, D. Z; BRIBIAN, I. Z.; SASTRESA, E. L. Environmental-benefits analysis of two urban waste colletion systems. Science of total Environment., London, v. 463-464, p. 72-77, may, 2013. http://dx.doi.org/10.1016/j.scitotenv.2013.05.053

VIEIRA, D. E. A.; BENETTON, M. L. F. N. Environment Factors Associate With the Occurrence of Enteroparasitosis in Patients Assisted in the Public Heath Net in Manaus, State of Amazonas, Brazil. Biosci. J., Uberlândia, v. 29, n. 2, p. 487-498, mar./apr. 2013.

VRIJHEID, M. Health effects of residence near hazardous waste landfill sites: a review of epidemiologic literature. Environ Health Perspect., London, v. 108(Suppl.1), p. 101-112, mar., 2000. 